\title{
Reestablishing a Healthy and Resilient North America-Linking Ecological Restoration with Continental Habitat Connectivity
}

\author{
Keith Bowers and Margo McKnight
}

T

The Northern Appalachians are one of the most intact temperate broadleaf forests in the world. However, this extraordinary region is increasingly at risk of being fragmented into a series of disconnected ecological islands by second-home development and roads. A 2011 study by The Nature Conservancy concluded that forests in this region are highly fragmented by 1.2 million $\mathrm{km}$ of permanent roads, enough to loop the equator 29 times (Trombulak et al. 2008). Nearly half the forest occurs in blocks $<2,000$ ha (about 5000 acres) in size that are encircled by major roads, resulting in an almost $60 \%$ loss of local connectivity.

This loss of local connectivity presents significant challenges to animal populations in their efforts to simply meet their basic life needs. Many species of wildlife need to move great distances, find food and breeding areas, migrate between winter and summer habitats, or disperse from an overcrowded natal territory. Large carnivores, such as American black bears (Ursus americanus), can range up to $16 \mathrm{~km}$ in a single day and up to $155 \mathrm{~km}$ over the course of a season, while occasional long-distance movements of dispersing or relocated animals can exceed $500 \mathrm{~km}$ (Powell 1997).

Unfortunately, the Northern Appalachians are not alone when it comes to fragmentation of wildlife habitat and corridors. Across North America and the world, habitat for keystone species, which require large ranges to forage, find mates, and thrive, and which occur in relatively lower numbers but have a disproportionate effect on the health and resiliency of their ecosystem, is disappearing at unprecedented rates. Many scientists cite loss of habitat as the biggest contributor to our current extinction crises.

As species extinctions and extirpations increase due to this lack of wildlife habitat connectivity, the effort to create networks of core protected areas connected by protected wildlife linkages has become an essential conservation priority to ensure the long-term survival of wide-ranging

Ecological Restoration Vol. 30, No. 4, 2012

ISSN 1522-4740 E-ISSN 1543-4079

C2012 by the Board of Regents of the University of Wisconsin System. wildlife. This loss of local connectivity compromises the gene pools of isolated populations, which in turn accelerates long-term regional loss of overall wildlife diversity, especially for small, shrinking, or threatened populations of species like Mexican wolves (Canis lupus baileyi) and black-footed ferrets (Mustela nigripes).

Finally, conservationists around the world are increasingly united by concern over the threats posed to the Earth's biological diversity by rapid human-induced climate change. Conservation biologists now agree that the best way to promote the survival of climate-threatened species is to establish resilient networks of connected and suitable habitats so that plants and animals can migrate to keep pace with changing environmental requirements.

Wildlands Network was created in 1991 when scientists, led by founder and father of conservation biology, Michael Soulé, began to realize none of North America's protected areas are large enough to sustain wildlife and nature for the long term. Animals, especially wide-ranging species, need large connected habitat to locate food and find mates. According to Soulé, "Our principal ambition is to create real, functional habitat connections on an unprecedented (continental) scale." It also has become very clear that large, connected habitat has significant benefits beyond these keystone species. Large carnivores, wide-ranging animals, and natural disturbance regimes are fundamental to the health of ecosystems because they perform essential regulatory functions, protect a large array of species, conserve life-supporting ecological processes, and provide resiliency in the face of climate change.

Wildlands Network envisions an intricate web of wildways interlinked throughout North America. The main strands of this web are 4 Continental Wildways (large corridors for wildlife) spanning North America's major mountain ranges and coasts: the Eastern, Western, Pacific, and Boreal Wildways. While public lands are certainly key to jump-starting these Wildways, even in western North America existing protected areas and public lands are inadequate to meet conservation connectivity goals. Major restoration efforts are needed on a scale not heretofore attempted. 
In November 2010, Wildlands Network co-hosted the first "Ecological Restoration for Continental Conservation" workshop with the Society for Ecological Restoration (SER) at the High Lonesome Ranch in DeBeque, Colorado. The workshop inspired a sea change that could have powerful implications on conservation at a continental scale. Although restoration happens locally, it can have a much bigger effect on large ecosystem integrity if planned strategically and could ultimately protect large scale migration corridors and populations of keystone species. Wildlands Network and SER seek to establish a strong collaborative relationship to align their conservation and restoration efforts in increasing landscape connectivity.

Wildlands Network presents a compelling and positive vision of large landscapes where all native species are present and ecological processes are functioning. Wildlands Network is different because it advocates for such conservation at the continental scale, via its campaigns in the Eastern, Western, Pacific, and Boreal Wildways. In many places within these Wildways, it is necessary to restore species and habitats in order to reach optimal, or near optimal, ecological conditions. For example, over $95 \%$ of the longleaf pine (Pinus palustris) forests of the Southeast coastal plain have been lost; restoration is the only way to bring back these iconic ecosystems and the species that depend on them, such as gopher tortoise (Gopherus polyphemus), Eastern indigo snake (Drymarchon couperi), and red-cockaded woodpecker (Picoides borealis).

To reverse the trend of habitat fragmentation and create functional habitat connections on a continental scale, ecological restoration will be needed. The goal of Wildlands Network's Ecological Restoration program is to increase the number and geographic scope of restoration projects in the Eastern and Western Wildways to re-establish landscape connectivity, large-scale migration corridors, and keystone species.

There is much to gain with a robust and collaborative partnership between the restoration community and the Wildlands Network. First, these wildways can provide a broader context and meaning to individual restoration projects that fall within their geographic boundaries. Second, policies and funding initiatives can be pooled and coordinated to work at several nested scales. Third, individual restoration projects can serve to engage the local community and demonstrate its connection to landscapescale processes. Finally, restoration of large-scale habitat connections can generate jobs, stimulate the economy, and lead to overall community health and resiliency. The result will be a restoration community catalyzed around a single vision of long-term continental scale nature protection.

At present, North America has thousands of good conservation groups and efforts. All are well worth supporting, yet they are not adding up to continental conservation. They are not tied together well enough to lead to continental wildways or national conservation corridors. Land and water conservation will need to be well coordinated, if we are to reconnect natural habitats coast to coast. North America needs both national and international conservation corridors initiatives.

In an effort to demonstrate this need, John Davis, Wildlands Network co-founder, set out from Everglades National Park (Florida) in January of 2011 to hike, paddle, and bike to Canada's Gaspe Peninsula in an effort to bring attention to the plight of wildlife, keystone species, and their need for habitat and connectivity across large landscapes.

A lifelong wildlands advocate, conservationist, writer, and explorer, Davis's inspiration for TrekEast (www.wild landsnetwork.org/trekeast) came while rowing and hiking with his friend, Bill McKibben - the renowned author of The End of Nature (1990) — on a regional wildways journey that resulted in McKibben's book, Wandering Home (2005). Other inspiration came from editing Dave Foreman's Rewilding North America (2004), as well as from his mother, the late Mary Byrd Davis, who completed the most comprehensive inventory of remaining Eastern old growth forest to date (Davis, 1996).

Davis slogged through swamps, hiked in search of rare prairies and longleaf pine forests, paddled pristine rivers, explored rich coastal marshes, and climbed ancient mountains. He also took side-trips from his charted course, to encounter as many critical wild places as possible.

Davis shared this journey with companion trekkers and important species, including the American crocodile (Crocodylus acutus), West Indian manatee (Trichechus manatus), common bottle-nosed dolphin (Tursiops truncatus), eastern oyster (Crassostrea virginica), American black bear, Florida panther (Puma concolor coryi), bobwhite quail (Colinus virginianus), wild turkey (Meleagris gallopavo), red-cockaded woodpecker, elk (Cervus canadensis), American bison (Bison bison), moose (Alces alces), North American beaver (Castor canadensis), and Canada lynx (Lynx canadensis). As he encountered their barriers to survival, Davis posted stories from the perspective of these threatened creatures and assessed wild places still present for us to connect.

\section{Components for an Eastern U.S. Wildway}

While conservation must play a significant role in realizing an Eastern Wildway, ecological restoration will be an absolute necessity. Here are 6 points Davis emphasizes to establish an Eastern Wildway.

1. Most of the East really is starved of large predators. When John Terborgh, Michael Soulé, Jim Estes, Reed Noss, Dave Foreman, Cristina Eisenberg, and others warn that our elimination of big animals, particularly top predators, from entire regions is having disastrous consequences, they do not exaggerate. (See for example several books published by Island Press: Saving Nature's Legacy, 1994; 
Continental Conservation, 1999, Rewilding North America, 2004; Trophic Cascades, 2010; and The Wolf's Tooth, 2010.) To be ecologically strong and healthy, America's ecosystems need wolves (Canis lupus, C. rufus), cougars (Puma concolor), and other keystone species throughout their native ranges. We now see that many Eastern deciduous forests are being deprived of their wildflowers and young hardwood trees by a ravaging surfeit of white-tailed deer (Odocoileus virginianus). It's not the deer's fault, but without their predators to keep them moving and hold their numbers in check, deer devour forest understories (Horsley 1998). Feral hogs (Sus scrofa) are worsening the damage. We should study how and where we might feasibly restore cougars and wolves to the wilder parts of the East. Carnivore recovery will only succeed if we protect big wild connected habitats (Maeher et al. 2001)

2. Waterways can be wildways. Restoring broad areas of natural vegetation along and around streams, lakes, and coasts wherever possible will restore habitat for fish and other aquatic animals, provide travel corridors for terrestrial mammals, soften effects of climate chaos, and improve water quality (Laenen et al. 1997). The quickest way to regain landscape-level connectivity may be by buffering waterways - as wide and wild as possible — together with linking existing protected areas. Closing and removing unneeded roads and dams in riparian areas will restore wildlife habitat and save taxpayer money. Riparian corridors are a particularly promising proposition in the Southeast Atlantic Coastal Plain province of the U.S., where rivers run slowly and flood widely, and much riparian forest still survives. Conservationists and planners should identify roads, culverts, and dams that fragment and pollute waterways and watersheds yet serve no vital community function, and that may be indefensible in the face of climate chaos. Through ecological austerity programs at local, state, and federal levels, such infrastructure should be carefully removed and natural ecosystems restored - to the benefit of thousands of people needing jobs and thousands of species deprived of habitat. Similary, wild waterways need to include big marine areas, for the benefit of wide-ranging fish, seals, whales, and seabirds.

3. Retrofitting roads with safe wildlife crossings can mitigate the effects of fragmentation and save wild animal and human lives (Forman et al. 2003). At the same time, heightened driver awareness and conscience (e.g., driving less often, in smaller cars, at slower speeds, and staying off roads at night) can reduce the tragedy of wildlife-vehicle collisions (Forman et al. 2003). In addition, modifying roads and culverts to make them more permeable to wildlife movement and more durable in the face of worsening storms and rising sea level may qualify as a promising restorative jobs program, boosting local economies and reducing unemployment. On the Florida leg of TrekEast,
Davis saw successful examples of wildlife underpasses (built for panthers and bears), but unfortunately he did not see similar examples in other states. He also saw unwise riprapping of streams and rebuilding of roads recently wiped out by severe storms, particularly Hurricane Irene. Seeing thousands of dead animals on roads across the trek made the lessons clear: our transportation systems are deadly, to both wildlife and people. Restoration of an Eastern Wildway depends on providing safe wildlife crossings under, over, and through roads and other infrastructure.

4. Private lands conservation is another key ingredient of continental wildway protection. Even out West, where much of the land is public, but most emphatically in the East, where the public domain is small, ample and connected habitats will only be achieved by providing private landowners strong financial and other incentives for maintaining natural vegetation and avoiding habitat fragmentation. Despite the noble efforts of the Land Trust Alliance, Nature Conservancy, and hundreds of smaller land trusts, most private lands have little or no protection, and financial pressures often force land-owners to "liquidate" their timber or subdivide for housing development. Continental wildways or national habitat corridor efforts must include conservation easements, property tax reform, and other tools that reward good care of undeveloped private lands. We also need a national carbon tax to penalize pollution and deforestation and fund habitat reconnection and energy retrofitting programs.

5. We need networks of people protecting networks of wildlands, as Michael Soulé has aptly said. If there are any issues around which a national consensus could be built in these politically polarized times, one may be the need to protect our natural heritage, and 3 others could be personal health, clean air, and clean water, all of which would be enhanced by a national and international conservation and recreation corridor system.

6. An Eastern Wildway should sweep through much of Florida and the Southeast Coastal Plain, follow rivers up through the Piedmont and into the Appalachians, then follow the mountains thousands of miles northeast (with lateral branches along rivers draining the mountains, and through the Pine Barrens, Adirondacks, Tug Hill Plateau, and other wildlands outside the Appalachian Mountains) to and through southern Quebec's Gaspe Peninsula. It should be a cohesive mix of public lands fully protected for their highest and best uses - as wildlife habitat, climate buffers, and quiet recreation grounds - and private lands protected by conservation easement and good financial incentives. All along TrekEast, Davis and Wildlands Network personnel found many places richly deserving and urgently needing protection. In at least 16 key locations throughout a future continental-scale Eastern wildlife corridor, or 
Eastern Wildway, opportunity and urgency are converging to call for immediate action. Davis and the Wildlands Network offer a sampling of great choices for restoration and conservation. Some of these are relatively small habitat linkages, but all are potentially parts of large wildlands complexes, and all are crucial parts of a future continental conservation corridor. Visit www.wildlandsnetwork.org/ node/664 to learn about these places where with modest steps, we can reclaim big parts of America's great natural heritage.

Establishing an Eastern Wildway will require a coordinated effort, effective policy and hard work, but most of all it requires vision. A vision that paints a brighter future, a vision that values our natural heritage, nurtures our cultural ideals and fosters economic prosperity. Ecological restoration must play a paramount role in that vision.

NOTE: In January 2013 Wildlands Network and its partners will launch TrekWest's $8,000-\mathrm{km}$ route through the Western Wildway. Davis will begin in Sonora, Mexico's Sierra Madre Occidental, follow the spine of the majestic Rocky Mountains, and end the trek at the "Crown of the Continent" in British Columbia. Combining his passion for nature and wilderness with a strong suit of perseverance, he will hike, bike, and paddle the West to reveal what stands to be lost and identify the solutions to create a western wildway that spans the continent. For more on the TrekWest and the Wildlands Network, visit www .wildlandsnetwork.org.

\section{References and Further Reading}

Davis, M.B. (ed). 1996. Eastern Old Growth Forest: Prospects for Rediscovery and Recovery. Washington DC: Island Press.
Eisenberg, C. 2011. The Wolf's Tooth: Keystone Predators, Trophic Cascades, and Biodiversity. Washington DC: Island Press.

Foreman, D. 2004. Rewilding North America: A Vision for Conservation in the 21st Century. Washington DC: Island Press.

Hannah, L. 2011. Saving a Million Species: Extinction Risk from Climate Change. Washington DC: Island Press.

Hannibal, M.E. 2012. The Spine of the Continent: The Most Ambitious Wildlife Conservation Project Ever Undertaken. Guilford, CT: Lyons Press.

Horsley, S.B., S.L. Stout and D.S. DeCalista, 2003. Whitetailed deer impact on the vegetation dynamics of a northern hardwood forest. Ecological Applications 13:98-118.

McKibben, B. 2005. Wandering Home: A Long Walk Across America's Most Hopeful Landscape: Vermont's Champlain Valley and New York's Adirondacks. New York, NY: Crown Publishing Group.

Nicholls, S. 2011. Paradise Found: Nature in America at the Time of Discovery. Chicago, IL: University of Chicago Press.

Noss, R.F. 1994. Saving Nature's Legacy: Protecting And Restoring Biodiversity. Washington DC: Island Press.

Soulé, M. and J. Terborgh (eds). 1999. Continental Conservation: Specific Foundations of Regional Reserve Networks. Washington DC: Island Press.

Terbough, J. and J. Estes (eds). 2010. Trophic Cascades: Predators, Prey, and the Changing Dynamics of Nature. Washington DC: Island Press.

Keith Bowers, FASLA, PWS, President, Board of Directors, Wildlands Network; President, Biohabitats, Inc., 2120 Noisette Boulevard, Suite 106B, Charelston, SC 29405, 843-529-3235, kbowers@biohabitats.com.

Margo McKnight, Executive Director, Wildlands Network, 11022 Bonnet Hole Drive, Thonotosassa, FL 33592, 813-9829534,margo@wildlandsnetwork.org. 